Reprinted with permission from: Noxious Range Weeds. 1991. Chapter 9. pp. 83-102.

Published by: Westview Press, Boulder, San Francisco, \& Oxford.

\title{
Biological control of rangeland weeds
}

P. C. QUIMBY, JR., W. L. BRUCKART, C. J. DELOACH, LLOYD KNUTSON, and M. H. RALPHS

\begin{abstract}
:
Weedy forbs and brush cost America's range managers at least $\$ 1.7$ billion/year. Biological controls, or "the planned use of living organisms to reduce the vigor, reproductive capacity, density, or effect of weeds," should be considered and included in pragmatic integrated weed management systems for rangelands. Various approaches to biocontrol under that definition are discussed. These include foreign exploration and introduction of exotic insects, notes, and plant pathogens as biocontrol agents; augmentation of native biocontrol agents, especially plant pathogens; grazing systems; and positive and aversion conditioning for various classes of livestock to use against troublesome weeds or brush or to avoid palatable poisonous weeds. USDA's Agricultural Research Service has at least nine laboratories, worldwide, devoted to research on various aspects of biocontrol of exotic and native rangeland weeds. The usual goal of biocontrol is to improve ecological systems by using biotic agents to restore target plant species to lesser competitive intensities or to negate their effects so that they do not overwhelm plant communities or cause damage to livestock. The usual results of biocontrol are: improved agricultural production, improved ecosystem functions and status in terms of species richness and diversity of plant and animal communities, and improved protection of rare species. Regardless of whether target weeds are introduced or native, researchers must make balanced evaluations of risks, benefits, and the potential for success in developing biological control programs.
\end{abstract}

\section{Introduction}

Weedy forbs and brush cause more losses on America's approximately 252 million hectares of rangeland than all other pests combined. An estimated 136 million hectares are infested with weeds and brush and the annual cost is at least $\$ 1.7$ billion (1). This estimate may be low by at least an order of magnitude when we consider the recent example of just one species' total economic impact. Thompson et al.(2) reported that 400,000 ha of leafy spurge in North Dakota cost that state $\$ 105$ million annually. Losses to poi- 
sonous plants were estimated in 1989 to exceed $\$ 340$ million/year in the 17 western states (3). Thus, control of weeds and brush is vital to overall vegetation management.

Biological controls should be considered and included in pragmatic integrated weed management systems, which are in turn essential to integrated rangeland vegetation management systems. The purpose of this paper is to review the background of biological control of weeds of rangelands, review the steps required in an introductory (classical) biological control program, discuss the use of plant pathogens, discuss grazing and aversion/positive conditioning of livestock as approaches, and provide some general information about ongoing projects.

\section{Definition of biological control of weeds}

Peter Harris (4) of Agriculture Canada defined biocontrol of weeds as "the use of undomesticated organisms that feed on the pest for the purpose of reducing its density, vigor, or reproduction."

For the purpose of this paper, we will use a modified version of a broader definition (5): "the planned use of living organisms to reduce the vigor, reproductive capacity, density, or effect of weeds." Under this broader definition of biological control, we can employ various approaches: introduction of exotic biocontrol agents (classical); augmentation of native biocontrol agents (such as use of mycoherbicides); grazing systems and positive conditioning that enable livestock of various classes to consume troublesome weeds or brush; grazing desirable forage in ways that help keep weeds in check; aversion conditioning of livestock to avoid palatable poisonous weeds; and the use of superior, fast-growing forages that can successfully compete with troublesome weeds (the latter is discussed in other papers during the symposium).

Research is currently in progress at nine ARS laboratories to control at least 16 genera and more than 30 species of rangeland weeds (Table 9.1). Any or all of the above approaches to biological control can be used alone or in combination as components in integrated range management systems that might also employ cultural practices such as burning, fertilizing, chaining, and treating with herbicides. Although many scientists from other countries, State Agricultural Experiment Stations, the Extension Service, and other federal and state agencies are involved in various aspects of research and implementation in these areas, this paper will focus primarily on contributions and activities of USDA's Agricultural Research Service. 
Table 9.1. Biological control of weeds: ARS labs and their major rangeland weed targets.

\begin{tabular}{|c|c|}
\hline Argentina-Hurlingham & $\begin{array}{l}\text { Snakeweed (Gutierrezia spp.), creosote-bush (Larrea spp.), tarbush } \\
\text { (Flourensia spp.) }\end{array}$ \\
\hline California-Albany & $\begin{array}{l}\text { Starthistles (Centaurea spp.), toadflax (Linaria spp.), gorse (Ulex eu- } \\
\text { ropaeus); potential new targets = dyer's woad (Isatis tinctoria), Scotch } \\
\text { thistle (Onopordum acanthium), poison hemlock (Conium maculatum) }\end{array}$ \\
\hline Italy-Rome & $\begin{array}{l}\text { Knapweeds and starthistles (Centaurea spp.), leafy spurge (Euphorbia } \\
\text { esula), thistles (Carduus, Cirsium), saltcedar (Tamarix chinensis) }\end{array}$ \\
\hline Maryland-Fort Detrick & Knapweeds, thistles, starthistles, leafy spurge (plant pathogens) \\
\hline Missouri-Columbia & $\begin{array}{l}\text { Cropland weeds and leafy spurge (soil microbes) (in cooperation with } \\
\text { Sidney, MT) }\end{array}$ \\
\hline Montana-Bozeman & $\begin{array}{l}\text { Knapweeds, leafy spurge, thistles, St. Johnswort (Hypericum perfora- } \\
\text { tum), larkspur (Delphinium spp.); potential new targets = dyer's woad } \\
\text { (Isatis tinctoria), whitetop (Cardaria draba), field bindweed (Convol- } \\
\text { vulus arvenis) }\end{array}$ \\
\hline Montana-Sidney & Leafy spurge \\
\hline Texas-Temple & $\begin{array}{l}\text { Snakeweed, saltcedar, creosotebush, field bindweed, cocklebur (Xan- } \\
\text { thium spp.), bitterweed (Hymenoxys spp.) }\end{array}$ \\
\hline Utah-Logan & $\begin{array}{l}\text { Larkspur, and various other weeds through aversion and preference } \\
\text { conditioning of different classes of livestock }\end{array}$ \\
\hline
\end{tabular}

Adapted from Quimby et al. (5).

\section{Biological control approaches}

\section{Introduction of exotic biocontrol agents (classical approach)}

This approach to biological control has recently been reviewed (6-8). Traditionally, the "classical" approach to biological control has involved the introduction of exotic natural enemies for control of exotic weeds and brush, but more recently has been applied to control native weeds. In 1985, Johnson (9) examined, from the point of view of plant ecology, the effects of species removals and introductions on ecosystem function. He found that the paleoecological record clearly shows that species composition of communities always has been, and still is, changing. However, at the ecosystem level, these changes in species composition (such as past natural or accidental catastrophic reductions in species abundance or in biocontrol successes) have not noticeably affected gross ecosystem structure and functional processes such as primary production and energy flow. Also, Johnson (9) could not distinguish any basic ecological differences between introduced weeds and native species that had weedy tendencies except that the introduced species lack natural herbivores. Thus, Johnson's thoughtful analysis has provided interesting scientific counterpoint to earlier concern (10) that biological control of native weeds might cause unwanted serious consequences in ecosystems. Moreover, no weed nor non-target plant species has been pushed near an endangered status by the introduction of a successful biocontrol organism $(6,11,12)$. 
Through environmental and econonmic necessity, the Agricultural Research Service has broadened the scope of its program in the introductory approach to biological control of weeds to include native target species. Most of the native species of weeds and brush targeted for biological control are in the Southwest, while exotic species are in the Central Plains and the Northwest (Table 9.2).

Table 9.2 Type and distribution of major weeds of western U.S. rangelands. ${ }^{a}$

\begin{tabular}{lccc}
\hline & \multicolumn{3}{c}{ Number of Species } \\
\cline { 2 - 4 } Type weed & Northern & Central & Southern \\
\hline Introduced & 11 & 5 & 0 \\
Herbaceous & 0 & 1 & 2 \\
Woody & 11 & 6 & 2 \\
Native & 9 & 13 & 3 \\
Herbaceous & 6 & 12 & 16 \\
Woody & 15 & 25 & 19 \\
& & &
\end{tabular}

${ }^{\mathrm{a}}$ summarized from Platte (13)

Thus, we can apply George B. Vogt's (personal communication) goal for biocontrol to both exotic and native weeds, viz., "to establish ecological systems so that the presence of biotic agents restores the target plant species to reduced competitive intensities where they do not overwhelm plant communities." Applying principles of introductory biological control for native weed targets is more difficult than for introduced targets because foreign insects introduced to control indigenous plants are less likely to be host-specific to the native target weed since the biotic agents occur on different host plants in their land of origin (14). On the other hand, "new associations" of biotic agents and target plants can sometimes result in greater efficacy of control because of a lack of co-evolutionary resistance on the part of the target (15). We should also cite Goeden and Kok (16), who have provided examples of successful biocontrol of weeds projects that do not represent "new associations." Regardless of whether the target weeds are introduced or native, researchers must consider and deal with conflicts of interest, which have been discussed in detail by Turner (17).

One of the major conflicts of interest over biocontrol of weeds programs has been concern about potential damage to endangered and threatened plant species closely related to target species (17). While no intentional introduction of a weed biocontrol agent into a given country has placed any known endangered plant species at risk, practitioners of the art and science of biocontrol have to be aware of the potential for that to happen (18). For example, the natural dispersal of Cactoblastus cactonuin into Florida from intentional establishments in the Caribbean has created fears that this moth species may attack endangered Opuntia spp. (19). Every effort must be expended to introduce biotic agents that will provide the greatest benefit with the least risk. Harris (8) has suggested that introduced stenophagous insects pose little risk to rare species because of their tendency to use the most abundant host. 
Pemberton (20) has cited Cates (21) who reported that about half of 22 "monophagous" insect species preferred the "rarest" of all the plant species on the same sites. Cates' definitions need to be considered in his work with "polyphagous," "oligophagous," and "monophagous" species. For example, by his definition, "oligophagous" herbivores "are restricted to feeding on two or more genera in a family or closely related families." Biocontrol workers would generally consider an oligophagous insect phytophage as one feeding on more than one plant species within a genus. Moreover, Cates' "rarest" plant species in his tests were not really "rare" in the sense of being endangered. Also, Cates did not indicate what effect the insects had on the density of the host plants; were certain plant species at low densities because of insect attacks? Further, Cates' data showed a wide range of variability in responses which leave the interpretations open to some question. The bottom line is that much more research is needed to settle this vital question of rare host plant/insect interactions.

Current procedural steps in the introductory approach are designed to take advantage of the knowledge we possess to produce maximum protection of the environment. These steps are as follows for USDA-ARS scientists: (1) select target and submit proposal for approval of the ARS National Program Staff Biological Control Matrix Team; (2) after receiving ARS approval, submit proposal to conduct research on the candidate target weed for review and approval of USDA, APHIS-PPQ's interagency advisory committee, i.e., the Technical Advisory Group for the Introduction of Biological Control Agents for Weeds (TAGIBCAW) (22); (3) examine herbaria/museum collections for information on potential biocontrol agents, study biogeography of weed/biotic agents in land of origin and in their new home; (4) explore foreign lands for host-specific natural enemies; (5) characterize biology/taxonomy/ecology/host range of candidate biological control agents [note: some of this research may be conducted under quarantine which requires petitions as regulated by USDA, APHIS-PPQ advised by TAGIBCAW and a similar group in Canada]; (6) release experimentally over range of habitats/time (note: releases are regulated more strictly than introduction into quarantine in that they require petitions to TAGIBCAW and environmental assessments as well as applications for field release pemits); and (7) release for implementation and evaluate progress with time, monitor efficacy, and determine economic effect. Steps 1-5 are research functions and are typically performed by federal and/or state research agencies. Steps 6-7 are research/implementation functions and the lines of responsibility may overlap between federal/state research agencies and federal/state action agencies. Private companies are sometimes involved in Step 7. Cooperation and communication are essential, especially in the early stages of a release program, to obtain maximum benefit from often scarce numbers of biocontrol agents.

Our knowledge of the principle and procedures involved in the various steps of the research protocol has increased greatly during the expansion of biological control of weeds research in North America and worldwide, especially since 1945, beginning with the review of Huffaker (23) in 1957. Since then the methodologies of target weed selection (14), foreign exploration (24-26), selection of the most promising control agents $(27,28)$, and host-range testing $(29,30)$ have been greatly refined. Newly developing technologies such as enzyme electrophoresis and DNA analysis add valuable tools to determine phylogenetic relationships, to match control agent and weed biotypes, and to detemine the biochemical determinants of specific attraction.

Page 5 of 15 
We need to determine host range relative to the degree of relatedness between a target weed and nontarget species. This becomes more difficult (and more important) if nontarget natives (potential hosts) are closely related to the target weed.

Vogt (31) has reported that susceptibility of plants to biotic agents is a continuum, i.e., it involves a spectrum of degree in responses. Behavioral changes often precede morphological changes in evolution; this adds to the complexity of selecting and testing "strains" and "isolates" of natural enemies. We are conducting research to help us understand the molecular basis for these plant/biotic agent interactions, so that we will be better able to assess benefits and risks of introductions. Coupled with this, then, is an ongoing research need to develop more complete information on taxononmic and biogeographic relationships worldwide among target and nontarget hosts and among "strains" or "isolates" of biotic agents. Also, this information will help us to determine objectively the relative nativeness ${ }^{1}$ of target and nontarget hosts as a factor in benefit/risk analysis.

Harris (7) has provided recent information on the costs of conducting biological control programs against weeds. Finding and testing a biotic agent may cost about $\$ 400,000$ for each agent. Establishing biological control of one weed may take 20 scientist years (SY's) and cost about $\$ 4$ million. Benefit:cost ratios for successful projects typically exceed 50:1 (32,33). As DeLoach et al. (34) point out, total cost of a program remains constant regardless of the area treated, but cost/unit area decreases as larger areas are controlled, and decreases still more with each added year of control. This makes the method particularly attractive for rangelands with low economic return.

In several cases, control of a given weed by one insect species or pathogen has been dramatic. However, introductory biological control is not a "silver bullet" that will solve all weed problems. When we consider the arid western rangelands since 1940, introductory biological control has been attempted for 23 species of weeds; only six $(26 \%)$ of these weed species so far have been completely or substantially controlled in larger areas (12). These include St. Johnswort (Hypericum perforatum), puncture vine (Tribulus terrestris), tansy ragwort (Senecio jacobaea), musk thistle (Carduus nutans), skeletonweed (Chondrilla juncea), and to a lesser extent, toadflax (Linaria vulgaris and L. dalmatica). In fact, research is still continuing on all the above except for puncture vine and tansy ragwort. We need a comprehensive analysis of these successes and failures. Some are still in progress as incomplete, unfinished projects. We should determine why success has not been achieved on some of the targets and how success can be realized on all or most of the targets.

The usual effect of controlling a dominant introduced weed with an introduced control agent is that the weed is replaced by a mixed community of plants that include the weed at a low density (8). For example, the control of St. Johnswort in California allowed ranges to return to their bunch grass climax and increased plant diversity by at least $35 \%$ (35). The weed probably will, however, continue to spread geographically into its range of climatic and edaphic adaptability.

\footnotetext{
${ }^{1}$ Johnson (9) used the terms "new natives" and "old natives" to describe the relativity of nativeness in plant origins.
} 
The objective of some land managers of complete absence of the weed is not necessary if biological control is in effect. The presence of a few plants does not signal a future serious infestation. However, in the case of some weeds highly toxic to livestock, biocontrol agents may not be able to maintain weed populations below the economic loss threshold and spot treatment with other types of control (such as herbicides) may be necessary.

The development of an introductory biological control program for a given weed may take several years, and may not even be possible for some weeds. In the meantime, land managers must use other practices to manage weeds. However, land managers should be willing to have a part (often only a small area) of their land used as establishment sites for biocontrol agents and they should manage their options to protect and favor them. The land managers may have to extend the protected areas if and when the agents become effective and spread. More research will be required on integrated approaches to provide guidance to those managers on cultural practices and grazing systems that will be compatible with biological control agents.

\section{Research at overseas biological control laboratories}

Overseas research on biological control of rangeland weeds is currently underway at ARS laboratories in Rome, Italy, Hurlingham, Argentina, and Beijing, Peoples Republic of China (PRC). This research is coordinated by the USDA-ARS-NPS Matrix Team for Biological Control and administered by ARS International Activities. These laboratories have a group of permanent scientists and technicians who conduct explorations for new natural enemies (insects, mites, and pathogens), conduct research, especially on the life cycles and host ranges of candidate control agents, and ship approved living control agents to U.S. quarantine facilities for further testing and eventual release in the field. They assist and cooperate with federal, state, and university biocontrol of weeds specialists. The U.S. cooperating scientists often visit for periods of a few days to a few months to establish projects, make explorations, and review progress.

\section{Research at Rome}

Since being established in Rome in 1959, with substations in Thessaloniki (1981) and Montpellier (1989), the USDA-ARS Biological Control of Weeds laboratory-Europe (BCWL-E) has emphasized U.S. western rangeland weeds of Euroasian origin. The laboratory explores for new natural enemies (insects, mites, and pathogens); conducts research, especially life cycle studies and host-specificity testing; and ships extensive living material to stateside colleagues and works with them to establish new natural enemies (36).

The laboratory serves as a focal point for U.S. biocontrol of weeds interests in Europe, Africa, the Middle East, and the USSR. Laboratory programs are coordinated with IIBC, Delémont, Switzerland; CSIRO, Montpellier, France, PL-480 projects in the Plant Protection Institute, Yugoslavia; and other biocontrol of weeds units. Explorations occur primarily in southern and eastern Europe, and since 1989 in the USSR and PRC. Biological studies are carried out in the field and laboratory and various host specificity 
tests are conducted in quarantine. Several insect species as weed biocontrol agents have been approved recently for release or study in U.S. quarantine, and shipment of living material to ARS, APHIS-PPQ, and state collaborators has been emphasized.

Leafy spurge is the highest priority target weed. Other prime targets are knapweeds, yellow starthistle, musk thistle, and recently, tamarisk (Tamarix spp.). Gorse (Ulex europaeus), dyer's woad (Isatis tinctoria), whitetop (Cardaria draba); common toadflax (Linaria vulgaris); weedy species of grasses, Spanish broom (Spartium junceum), cutleaf geranium (Geranium dissectum), and others are being considered as new targets. The natural enemies being researched are covered in other papers in this proceeding.

Future emphasis will include (depending on funding and staffing) more experimental studies on competition between natural enemies and on the interrelationships of the members of natural enemy guilds on target weeds; quantification of impact on target weeds, site specificity based on natural enemy habitat characterization, both biologically and physically at micro and macro habitats; and genetic characterization of biotypes by electrophoretic and other methods.

\section{Buenos Aires}

The ARS Biological Control Laboratory was established near Buenos Aires in 1960. Early research resulted in the successful control of the aquatic weeds alligatorweed $(\mathrm{Al}$ ternanthera philoxeroides), waterhyacinth (Eichhornia crassipes), and waterlettuce (Pistia stratiotes). Since 1974, research at Hurlingham (a suburb of Buenos Aires) has concentrated on control of native rangeland weeds of the Southwestern U.S. Several of these most important weeds are from genera with disjunct distributions that include different species native in each area. The natural enemies found and introduced are necessarily "new associations" (15) as discussed above.

The laboratory serves as the focal point for research in all of southern South America, and excellent contacts exist with weed scientists, entomologists, and taxonomists in local universities and federal and provincial research stations in these countries. Explorations are made in countries from Brazil and Bolivia southward and detailed biological and host range studies are conducted in the field in Argentina and in the laboratory at Hurlingham.

Primary target weeds at present are snakeweeds and broomweeds (Gutierrezia spp.), creosotebush (Larrea spp.), and tarbush (Flourensia spp.). Much exploration was previously done on mesquite (Prosopis spp.) and Baccharis spp. Several other weeds could be considered for future research, such as bitterweed (Hymenoxys spp.), sneezeweed (Helenium spp.), dogfennel (Eupatorium spp.), loco (Astragalus spp.), whitebrush (Aloysia spp.), alfombrillo (Drymaria spp.), and others, plus many important crop weeds.

\section{Plant pathogens for biological control}

In nature, most plants are attacked by several to many plant pathogens when climatic conditions are correct. Many of these appear to be promising biocontrol agents in greenhouse studies, but some are unsuccessful in field tests because their microdimatic conditions for infections may not be met there. In the 1970s, Australian scientists had great 
success in controlling the European skeletonweed (Chondrilla juncea) with an introduced European rust, Puccinia chondrillina. This stimulated much research and $P$. chondrillina was released in California and the Northwest in 1978; it has been the most effective of three biocontrol agents in California (37). In addition, two crop weeds have been controlled with native pathogens, northern jointvetch (Aeschenomene virginica) in Arkansas rice fields and stranglervine (Morrenia odorata) in Florida citrus orchards. Recent research has produced breakthroughs that can overcome many of the early difficulties encountered in using plant pathogens in the field.

Evaluation of foreign plant pathogens for introduction into the U.S. is conducted in a containment greenhouse located in Frederick, MD (38). This laboratory is screening more than 150 acquisitions of stem, leaf, and soil-borne (including wilt) pathogens collected by Rick Bennett (ARS), David Sands from Montana State University, and Genevieve DeFago at the Eidgenossische Technische Hochschule in Zurich, Switzerland. These acquisitions are from several countries in Eastern Europe and the Soviet Union. Philosophy and procedures for the evaluation of these candidate organisms have been described (39).

Major targets for biological control using introduced plant pathogens are: leafy spurge (Euphorbia esula-virgata complex), musk thistle (Carduus thoermeri), the knapweeds (Centaurea diffusa and C. maculosa, and the starthistles (C. calcitrapa and C. solstitialis).

\section{Leafy spurge.}

Presently, most work has been on the evaluation of an Alternaria sp., a leaf-spotting fungus first isolated in North Dakota by Krupinski (40). Since then, another Alternaria sp. collected in Nebraska has been included in the evaluations. Development of disease in preliminary greenhouse studies required at least a 24-hour dew period, which is a situation rarely found in the field. However, a formulation of the pathogen in a water-in-oil invert emulsion (41), which was modified and applied through standard air pressure sprayers, allowed infection in the absence of a dew period. This formulation was used in field trials in Nebraska and North Dakota in 1990.

\section{Musk thistle.}

Of seven Carduus species introduced into North America from Eurasia, musk thistle is the most widespread. Dunn (42) considered it economically important in $10 \%$ of the counties in the U.S. Puccinia carduorum has been found causing a rust disease throughout the distribution of musk thistle in Eurasia since 1978. A strain from Ankara, Turkey, is among the most virulent and was selected for extensive study. Although host range tests revealed the pathogen to be most aggressive on musk thistle, minor infections occurred in the greenhouse on one of three additional species of Carduus, on artichoke $(C y$ nara scolymus), and on 8 of 16 species of Cirsium (43). Seedlings and young plants of these species were the most susceptible and plants six to seven weeks old (from planting) were very difficult to infect. Also, reinoculation of symptomatic plants usually did not result in new infections; in a few cases, disease severity was greatly reduced.

A proposal to APHIS to conduct a limited field evaluation of $P$. carduorum was initiated in 1984, amended in 1985, and approved in October 1987 following completion of an Environmental Assessment. The first inoculations were made at a site near Blacksburg, VA, in cooperation with scientists at Virginia Polytechnic Institute late in the same 
month. Musk thistle in the plots developed high levels of disease and diseased plants were found at least $100 \mathrm{~m}$ outside of the plot area. None of the five Cirsium species developed symptoms of infection, and only one small pustule was found on one of 35 artichoke plants late in the second year. A proposal has been made to APHIS for permission to use this pathogen without restriction for biological control of musk thistle in the U.S.

\section{Starthistles and knapweeds.}

These plants are susceptible to a rust disease caused by Puccinia jaceae introduced from Europe. Like the musk thistle rust, it produces some nontarget effects, i.e., a limited infection on safflower (Carthamus tinctorius) (44). In quarantine tests, $P$. jaceae caused much less infection on safflower than did $P$. carthami (which causes an inconsequential safflower rust in North America), and resistance to safflower rust may confer resistance to $P$. jaceae (44). In Canada, severity of disease caused by the diffuse knapweed strain of $P$. jaceae declined as the age of safflower plants increased at time of inoculation $(45,46)$.

A strain of P. jaceae from yellow starthistle is under consideration by APHIS for limited field evaluation in California. Proposals are being developed for release of three other strains of $P$. jaceae from purple starthistle, diffuse knapweed, and spotted knapweed.

Another approach to control knapweeds, being investigated by David Sands at Montana State University, is the augmentation of Sclerotinia sclerotiorum, a fungus with a broad host range (47). Among several mutants tested, one does not produce overwintering sclerotia and so it would not persist and pose a threat to subsequent desirable forbs in a treated location. If this approach can be developed, it would provide a biological substitute for the commonly used 2,4-D herbicide.

\section{Livestock as biological control agents for weeds}

Differential grazing habits, preferences, and selective abilities of livestock species may allow them to exert selective grazing pressure against some weeds that would result in effective control while providing an economic return. Brock (48) listed four conditions which must be met for livestock to be effective biocontrol agents:

1. The target plant must be accepted by livestock as forage.

2. The target plant must have a differential susceptibility to grazing at some time of the year to aid in the control strategy.

3. Other forage plants must be present to replace the target species.

4. Livestock must be controlled closely.

Different animal species are suited to utilize different types of plants. Hanley (49) proposed a framework for forage selection strategies among animals based on morphological characteristics: body size, type of digestive system, ruminoreticular volume/body weight ratio, and mouth size. Cattle, as the largest domestic species, have large rumens and long retention times that enable them to digest low-quality, high-cellulose diets. Their large mouths render them less selective, thus they are suited to ingest large amounts of low-quality fibrous forage. 
Goats, as the smallest domestic species, have small rumens, a short retention time, and a high relative nutrient requirement. Their small mouth and nimble lips allow them to be very selective. They are suited to selecting shrubs, digesting the cell contents and rapidly passing undigestible lignin. Sheep are intermediate, having a small body size, yet a large ruminoreticular volume/body size ratio. Their small mouths and nimble lips enable them to be selective, yet they have the rumen capacity to digest low-quality roughage.

The morphological characteristics that enable a goat to utilize shrubs and their observed preference for shrubs have led to their use in brush control systems. In Texas where goats are a viable economic enterprise, they have been used to control resprouts of shin oak (Quercus mohariana), liveoak (Q. virginiana), mesquite (Prosopis qlandulosa) and juniper (Juniperus ashei and J. pinchoti) following chaining to knock down mature trees $(50,51)$. Goats have been successful in defoliating regrowth of brush species in burned over and seeded areas of chaparral in Arizona (52) and in fuel breaks in California (53). Heavy goat browsing of gambel oak (Q. gambelii) removed current year's growth in Utah (54) and in Colorado (55). Goats have been effective in converting brush-covered abandoned farmland to productive pastures in New England (56), and in controlling gorse (Ulex europaeus), the major scrubweed in productive pastures in New Zealand and Australia $(57,58)$. Sheep may also be effective in reducing brush and understory plant growth in coastal Douglas fir (Pseudotsuga menzieii) plantations; the reduced competition resulted in more rapid growth of commercial trees (59).

Sheep have the propensity to graze forbs selectively. One of the earliest recommendations for control of leafy spurge (Euphorbia esula) in the northern Great Plains was sheep grazing $(60,61)$. Sheep selectively grazed small, young leafy spurge plants in an infested crested wheatgrass (Agropyron cristatum) seeding and continued to graze the mature plants into the summer as crested wheatgrass matured and became unpalatable (62). In controlled grazing behavior studies sheep did not readily graze leafy spurge for the first 1-3 weeks, but increased consumption of spurge to $40-50 \%$ of their diets by midsummer $(63,64)$. Physical trampling damage by cattle in an intensive short-duration grazing system also controlled leafy spurge (65).

Sheep also appear successful in controlling tansy ragwort (Senecio jacobaea). Sheep defoliated tansy ragwort plants and prevented this biannual plant from going to seed (66). Grazed plants did not continue to grow the next year. West and Farah (67) reported that sheep grazed dyer's woad (Isatis tinctoria), but did not utilize it heavily enough late in the growing season to prevent seed production.

Cattle are less selective but can utilize areas not suited for sheep [such as bitterweed (Hymenoxys odorata), sneezeweed (Helenium hoopesii), cheatgrass (Bromus tectorum) and medusa head rye (Taeniatherum caput-medusae) ranges]. The potential also exists to train livestock to preferentially graze particular weed species. Animal species and individuals within a species exhibit a wide range of preference among plants. Preferences can be modified by experience, thus providing the opportunity to adjust selection patterns to graze particular plants to meet management objectives (68). Preferential grazing habits developed early in life influence subsequent diet selection. Provenza and Balph (69) describe three mechanisms to help young animals learn to select specific foods.

Page 11 of 15 
1. Food imprinting. During the period around weaning, when animals are in the transition between maternal care and independence, they apparently learn persistent food preferences. Squibb et al. (70) reported that 4- to 8-week-old lambs exposed to the shrub, mountain mahogany (Cercocarpus montanus), consumed more of the shrub when tested at five months and one year later than lambs exposed at younger or older ages. Lambs 4-8 wk of age are functional ruminants and are reducing their dependence on mothers' milk.

2. Social learning. Young animals learn what to eat from observing and participating with social models (mothers and "respected" adults). Lambs exposed to novel foods (rolled barley or serviceberry (Amelanchier alnifolia) with their mother or another adult consumed more of the novel food when tested 4 weeks later (71). Lambs ate more of the respective novel food when exposed with their mothers, an intermediate amount when exposed with another adult, and least when exposed alone.

3. Individual learning. Garcia and Koelling (72) coined the term cue-consequence specificity, meaning the taste of food can be related to its post-ingestive consequences (either positive or negative). Taste neurons converge with neurons from the gut in the emetic center of the brain. Feedback from the gut may be relayed along pathways recently activated by taste cues and associations are formed. If the consequence is positive (nutrient loading), the food acquires a palatable value. If consequences are negative (nausea or illness), the food becomes unpalatable. The taste of the food takes on hedonic value and varies in acceptability.

Principles of aversive conditioning have been developed for livestock $(73,74)$. Cattle have been trained to avoid eating larkspur, a palatable poisonous plant $(75,76)$. Sheep have been trained to avoid eating common foods (barley, corn, wheat, and shrubs in a nursery) $(71,73,77)$.

Positive conditioning is also possible. Mere exposure to a food increases an animal's acceptance of it (78). Pairing of beneficial consequence with taste of a food will increase the relative preference for that food. Most positive conditioning research has been performed on rats (79). Pairing a taste with caloric input, recovery from nutritional deficiencies, and recovery from post-ingestive distress will increase preference for that taste. There is no reason to assume preferences cannot be likewise shaped in livestock. The potential exists through diet training early in life to condition groups of livestock to graze specific weeds preferentially and thus be more effective biological agents in the fight against noxious weeds.

One major advantage of using various classes of livestock to graze noxious weeds preferentially is that a resource is being utilized and some income or gain can be derived from the practice, although training animals may have a cost, also. If the only goal is chemical control, then expenditures to achieve that may or may not be recouped with increased forage. A land manager would have to evaluate very carefully the economics and environmental consequences of various options for weed control. 


\section{Summary}

The "take-home" message that we would like to impart is that biological control can be and should be an important part of integrated weed management systems on North America's rangelands. Achieving successful management of troublesome species of rangeland weeds will require a continuous research effort coupled with effective, coordinated communication and cooperation among public research and action agencies and private land managers. The goal of weed management should be to economically complement other rangeland management practices that foster stable, complex ecosystems which have high energy flows, a wide diversity of plants and animals, and sound mineral and water cycles.

\section{References}

1. Anonymous. In: Report of the ARS (USDA) Research Planning Conference on Weed and Brush Control and Related Integrated Research on Rangelands, p. i, College Station, TX, 1982.

2. Thompson, F. F., L. Leistritz, and J. Leitch. Agric. Econ. Report No. 257, North Dakota State Univ., Fargo (1990).

3. Nielsen, D. B., N. R. Rimbey, and L. F. James. In: The Ecology and Economic Impact of Poisonous Plants on Livestock Production (L. F. James, M. H. Ralphs, and D. B. Nielsen, Eds.), pp. 5-15. Westview Press, Boulder, CO, 1988.

4. Harris, P. BioScience 38:542-548 (1988).

5. Quimby, P. C., A. L. Christy, R. D. Child, and R. S. Soper. In: Proc. National Grazinglands Weed Management Conference (E Lehnert, Ed.), pp. 81-86, 1990.

6. Schroeder, D. In: Recent Advances in Weed Research (W. W. Fletcher, Ed.), pp. 41-78. CAB, Slough, 1983.

7. Harris, P. In: Rangeweeds Revisited (B. F. Roché Jr. and C. T. Roché, Eds.), pp. 61-68. Proc. Range Manage. Shortcourse, Wash. State Univ., Pullman, 1989.

8. Harris, P. In: Critical Issues in Biological Control (M. Mackauer, L. E. Ehler, and J. Roland, Eds.), pp. 289-300. Intercept Ltd, Andover, Hants, UK, 1990.

9. Johnson, H. B. In Proc. VI Int. Symp. Biol. Contr. Weeds (E. S. Delfosse, Ed.), pp. 27-56. Canadian Government Publishing Centre, Ottawa, 1985.

10. Andres, L. A. In: Proc. V Int. Symp. Biol. Contr. Weeds (E. S. Delfosse, Ed.), pp. 11-20. CSIRO, Melbourne, 1981.

11. Goeden, R. D. In: Introduced Parasites and Predators of Arthropod Pests and Weeds: A World Review (CP Clausen, Ed.), pp. 357-414. USDA-ARS Agric. Handbook 480.

12. Julien, M. H. Biological Control of Weeds: A World Catalogue of Agents and Their Target Weeds, Second Ed. CAB Intl. Inst. Biol. Contr, Wallingford, UK, 1987.

13. Platte, K. B. J. Range Management 12:194-200 (1959).

14. DeLoach C. J. In: Proc. V Int. Symp. Biol. Contr. Weeds (E. S. Delfosse, Ed.), pp. 175-190. CSIRO, Melbourne, 1981.

15. Hokkanen, H. and D. Pimental. Canad. Entomol. 116:1109-1121 (1984).

16. Goeden, R. D. and L. T. Kok. Canad. Entomol. 118:51-58 (1986). 
17. Turner, C. E. In: Proc. VI Int. Symp. Biol. Contr. Weeds (E.S. Delfosse, Ed.), pp. 203-225. Canadian Government Publishing Centre, Ottawa, 1985.

18. Turner,C. E., R. W. Pemberton, and S. S. Rosenthal. Environ. Entomol. 16:111-115 (1986).

19. Kass, H. Plant Conservation 5:2 (1990).

20. Pemberton, R. W. In: Proc. VI Int. Symp. Biol. Control Weeds (E. S. Delfosse, Ed.), pp. 365-390. Canadian Government Publishing Centre, Ottawa, 1985.

21. Cates, R. G. Oecologia 48:319-326 (1981).

22. Coulson, J. R. and R. S. Soper. In: Plant Protection and Quarantine, Vol. III Special Topics (Kahn, R.P., Ed.), pp. 357-414. CRC Press, Inc., Boca Raton, FL, 1989.

23. Huffaker, C. B. Hilgardia 27:101-157 (1957).

24. Room, P. M. In: Proc V Intl. Symp. Biol. Control Weeds (E. S. Delfosse, Ed.), pp. 113-124. Brisbane, Australia, 1980.

25. Sands, D. P. A. and K. L. S. Harley. In: Proc. V Intl. Symp. Biol. Control Weeds (E. S. Delfosse, Ed.), pp. 81-89. Brisbane, Australia, 1981.

26. Wapshere, A. J. In: Proc. V Intl. Symp. Biol. Control Weeds (E. S. Delfosse, Ed.), pp. 75-79. Brisbane, Australia, 1981.

27. Harris P. Canad. Entomol. 105:1495-1503 (1973).

28. Goeden R.D. Prot. Ecol 5:287-301 (1983).

29. Zwölfer H. and P. Harris. Ann. Rev. Entomol. 16:159-178 (1971).

30. Wapshere A. J. Ann. Appl. Biol. 77:201-211 (1974).

31. Vogt, G. B. In: Insects of Panama and Mesoamerica: Selected Studies (D.Q. Arias and A. Aiello, Eds.), Oxford Univ. Press, Oxford, 1991.

32. Harris, P. Weed Science 27:242-250 (1979).

33. Andres, L. A. Aquatic Botany 3:111-123 (1977).

34. DeLoach, C. J., P. E. Boldt, H. A. Cordo, H. B. Johnson, and J. P. Cuda. In: Management and Utilization of Arid Land Plants (D. R. Patton, C. E. Gonzalez, A. L. Medina, L. A. Segura T., and R. H. Hamre, Eds.), pp. 49-67. Saltillo, Mexico, 1986.

35. Huffaker, C. B. and C. E. Kennett. J. Range Manage. 12:69-82 (1959).

36. Fornasari, L. and L. Knutson. In: Pesticides and Alternatives (J. E. Casida, Ed.), pp. 515-530. Elsevier Science Publishers, Amsterdam, 1990.

37. Supkoff, D. M., D. B. Joley, and J. J. Marois. J. Appl. Ecol. 25:1089-1095 (1988).

38. Melching, J. S., K. R. Bromfield, and C. H. Kingsolver. Plant Disease 67:717-722 (1983).

39. Bruckart, W. L. and W. M. Dowler. Weed Science 34 (Suppl. 1):11-14 (1986).

40. Krupinski, J. M. and R. J. Lorenz. Weed Science 31:86-88 (1983).

41. Quimby, P. C., F. E. Fulgham, C. D. Boyette, and W. J. Connick. In: Pesticide Formulations and Application Systems: Eighth Volume (D. A. Hovde and G. B. Beestman, Eds.), pp. 264-270. Amer. Soc. for Testing \& Materials, Philadelphia, PA, 1989.

42. Dunn, P. H. Weed Science 24:518-524 (1976).

43. Politis, D. J., A. K. Watson, W. L. Bruckart. Phytopathology 74:687-691 (1984).

44. Bruckart, W. L. Plant Disease 73:155-160 (1989).

45. Watson, A. K. and I. Alkoury. In: Proc. V Int. Symp. Biol. Control Weeds (E. S. Delfosse, Ed.), pp. 301-305. CSIRO, Melborne, 1981. 
46. Mortensen, K. In: Proc. VI Int. Symp. Biol. Control Weeds (E.S. Delfosse, Ed.), pp. 447-452. Canadian Government Publishing Centre, Ottawa, 1985.

47. Ford, E. J. In: Proc of the 1989 Knapweed Symp. (P.K. Fay and J.R. Lacey, Eds.), pp. 182-189. Montana State Univ., Bozeman, 1989.

48. Brock, J. H. Rangelands 10:32-34 (1988).

49. Hanley, T. A. J. Range Manage. 35:146-151 (1982).

50. Merrill, L. B. and C. A. Taylor. Rangemans J. 3:74-76 (1976).

51. Wiedemann, H. T., C. H. Meadors, and C. E. Fisher. Texas Agric. Exp. Sta. Consolidated Progress Report 3665 (1980).

52. Knipe, O. D. Rangelands 5:252-255 (1983).

53. Green, L. R., C. L. Hughes, and W. L. Graves. In: Proc. First International Rangeland Congress (D.N. Hyder, Ed.), pp. 451-455. Soc. Range Manage, Denver, CO, 1979.

54. Riggs, R. A. and P. J. Urness. J. Range Manage. 42:354-360 (1989).

55. Davis, G. G., L. E. Bartel, and C. W. Cook. J. Range Manage. 28:216-218 (1975).

56. Wood, G. M. Agron. J. 79:319-321 (1987).

57. Radcliffe, J. E. New Zealand J. Exp. Agric. 13:181-190 (1985).

58. Harradine, A. R. and A. L. Jones. Aust. J. Exp. Agric. 25:550-556 (1985).

59. Sharrow, S. H., W. C. Lieninger, and B. Rhodes. J. Range Manage. 42:2-4 (1989).

60. Wood, H. E. Manitoba Dept. Agric. Immig. Pub. 194 (1944).

61. Wood, H. E. Manitoba Dept. Agric. Immig. Pub. 200 (1945).

62. Johnston, A. and R. W. Peake. J. Range Manage. 12:192-195 (1960).

63. Landgraf, B. K., P. K. Fay, and K. M. Havstad. Weed Science 32:348-352 (1984).

64. Bartz, S. J., E. L. Ayers, and K. M. Havstad. In: Proc. Leafy Spurge Symp., p. 24. Sundance, WY, 1983.

65. Parman, M. Rangelands 8:183 (1986).

66. Sharrow, S. H. and W. D. Mosher. J. Range Manage. 35:480-482 (1982).

67. West, N. E. and K. O. Farah. J. Range Manage. 42:5-10 (1989).

68. Provenza, F. D. and D. F. Balph. Appl. Anim. Behav. Sci. 18:211-232 (1987).

69. Provenza, F. D. and D. F. Balph. J. Anim Sci. 66:2356-2368 (1998).

70. Squibb, R. C., F. D. Provenza, and D. F. Balph. J. Anim Sci. 68:987-997 (1990).

71. Thorhallsdottir, A. G., F. D. Provenza, and D. F. Balph. Appl. Anim. Behav. Sci. 18:327-340 (1987).

72. Garcia, J. and R. A. Koelling. Psychon. Sci. 4:123-124 (1966).

73. Lane, M. A., M. H. Ralphs, J. D. Olsen, F. D. Provenza, and J. A. Pfister. J. Range Manage. 43:127-131 (1990).

74. Ralphs, M. H. and J. D. Olsen. J. Anim. Sci. 68: (1990).

75. Thorhallsdottir, A. G., F. D. Provenza, and D. F. Balph. Appl. Anim. Behav. Sci. 25:25-33 (1990).

76. Burritt, E. A. and F. D. Provenza. J. Anim. Sci. 68:1003-1007 (1990).

77. Ralphs, M. H. Range Manage. (1991).

78. Zajonic, R. B. J. Personality and Social Psychology, Monograph Supp. 9:1-27 (1968).

79. Provenza, F. D., J. A. Pfister, and C. D. Cheney. J. Range Manage. (In Press) (1991).

Page 15 of 15 